\title{
ANALISIS PERBANDINGAN NET PROFIT MARGIN DAN GROSS PROFIT MARGIN PERUSAHAAN TELEKOMUNIKASI
}

\author{
Firda inayah $^{1}$, Aris Munandar ${ }^{2}$ \\ ${ }^{1,2}$ Manajemen Ekonomi, Sekolah Tinggi Ilmu Ekonomi (STIE) Bima, Bima
}

\begin{tabular}{l}
\hline ARTICLE INFORMATION \\
\hline ISSN: 2579-7204 (Online) \\
ISSN: 0216-4132 (Print) \\
DOI: $10.26487 /$ jbmi.v18i1.13722 \\
\hline SUBMISSION TRACK \\
\hline Received: $7^{\text {th }}$ May 2021 \\
Final Revision: $29^{\text {th }}$ May 2021 \\
Available Online: date, month, year \\
\hline KATA KUNCI \\
\hline Perbandingan; Net Profit Margin; Gross \\
Profit Margin
\end{tabular}

KEYWORD

Comparison; Net Profit Margin; Gross

Profit Margin

\section{CORRESPONDENCE}

Phone: 085239865899

E-mail:

firdainayah17.stiebima@gmail.com

\begin{abstract}
ABSTRAK
Penelitian ini bertujuan untuk mengetahui dan menganalisis perbandingan net profit margin dan gross profit margin. Yang menjadi obyek dalam penelitian ini adalah PT Telekomunikasi Indonesia Tbk dan PT XL Axiata Tbk. Hasil penelitiannya berkesimpulan bahwa berdasarkan uji independent sample t-test net profit margin dan gross profit margin sama-sama menunjukkan adanya perbedaan yang signifikan. Sebagaimana dasar pengambilan keputusan maka $\mathrm{H} 0$ ditolak dan Ha diterima dengan kesimpulan terdapat perbedaan karena nilai signifikannya $<0,05$.

\begin{tabular}{l} 
ABSTRACT \\
\hline This study aims to determine and analyze the \\
comparison of net profit margin and gross profit \\
margin. The object of this research is PT \\
Telekomunikasi Indonesia Tbk and PT XL Axiata Tbk. \\
The result of his research concluded that based on the \\
independent sample t-test, the net profit margin and \\
gross profit margin both showed a significant. As the \\
basis for decision making HO is rejected and Ha is \\
accepted with the conclusion that there is a difference \\
due value signifikant $<0,05$.
\end{tabular}
\end{abstract}

\section{PENDAHULUAN}

Industri telepon seluler pada era globalisasi seperti saat sekarang ini, memasuki babak baru, sehingga menyebabkan banyak perusahaan telekomunikasi bersaing meningkatkan kinerja perusahaan masing masing untuk menekan pertumbuhan laba. Saat ini teknologi komunikasi bukan hanya untuk melakukan telepon atau mengirim pesan singkat,tetapi juga sebagai media hiburan dan mengakses informasi dari seluruh penjuru dunia melalui layanan akses internet.

Jasa telekomunikasi seluler menjadi sebuah kebutuhan masyarakat yang sangat penting, karena fenomena ini para investor pun berlomba lomba dalam berinvertasi karena sektor ini menjadi salah satu pilihan sebagai investasi yang menjanjikan, seperti halnya yang berlaku pada perusahaan PT Telekomunikasi Indonesia Tbk dan XL Axiata Tbk karena kedua perusahaan ini telah go public dan tercatat di Bursa Efek Indonesia. Kedua perusahan ini dipilih karena selalu menghasilkan laba besar tiap tahunnya,dan 
diyakini juga bahwa keberadaan perusahaan di sektor telekomunikasi akan selalu eksis disebabkan karena merupakan salah satu kebutuhan pokok dari masyarakat.

PT XL Axiata Tbk dan PT Telekomunikasi indonesia Tbk adalah salah satu perusahaan telekomunikasi terkemuka di Indonesia dan menjadi perusahaan go publik yang telah terdaftar di BEI dan telah melakukan publikasi laporan keuangannya secara rutin serta memiliki kinerja keuangan yang berfluktuasi. PT XL Axiata Tbk dan PT Telekomunikasi Indonesia Tbk perlu dilakukan pengukuran kinerja keuangan salah satunya dari sisi rasio profitabilitas untuk mengetahui seberapa mampu perusahaan dalam menghasilkan laba atas penjualan sehingga manajemen perusahaan dapat mengetahui tingkat kinerja perusahaan yang dihitung dengan menggunakan rasio keuangan yaitu net profit margin dan gross profit margin

Menurut Muqorabin dan Nasar (2009) kinerja keuangan adalah hasil yang dicapai atas berbagai aktivitas yang dilakukan dalam mendayagunakan sumber keuangan. Menurut Jumingan (2008) rasio dalam analisis laporan keuangan adalah angka yang menunjukkan hubungan antara suatu unsur dengan unsur lainnya dalam laporan keuangan. Pratowo (2012) mengatakan bahwa analisis keuangan adalah suatu proses yang penuh pertimbangan dalam rangka membantu mengevaluasi posisi keuangan dan hasil operasi perusahaan pada masa sekarang dan masa lalu, dengan tujuan utama untuk menentukan estimasi dan prediksi yang paling mengenai kondisi dan kinerja perusahaan pada masa mendatang.

Berdasarkan pengertian para ahli terkait dengan perbandungan rasio keuangan yang digunakan dalam penelitian ini mengac u pada pendapat Kasmir (2009) yang meliputi (1) perbandingan horizontal merupakan perbandingan yang dilakukan dengan membandingkan laporan keuangan dari beberapa periode, menggambarkan informasi perusahaan yang sama tetapi untuk periode waktu yang berbeda. (2) perbandingan vertikal merupakan perbandingan yang dilakukan hanya satu periode laporan keuangan saja, menggambarkan hubungan pos pos laporan keuangan atau kondisi untuk satu periode saja sehingga tidak dapat mengetahui perkembangan kondisi perusahaan dari periode yang satu ke periode berikutnya. Dalam analisis perbandingan vertikal menggunakan analisis laporan keuangan.

Rasio Net profit margin di sebut juga dengan rasio penjualan. Beberapa pengertian net profit margin menurut para ahli diantaranya, mengenai profit margin ini Joel G. Siegel dan Jae K. Shim mengatakan margin laba bersih sama dengan laba bersih dibagi dengan penjualan bersih (Irham Fahmi, 2014). Ini menunjukkan kestabilan kesatuan untuk menghasilkan perolehan pada tingkat penjualan khusus. Dengan memeriksa margin laba dan norma industri sebuah perusahaan pada tahun-tahun sebelumnya, kita dapat menilai efisiensi operasi dan strategi penetapan harga serta status persaingan perusahaan dengan perusahaan lain dalam industri tersebut. Sebuah perusahaan akan di anggap baik apabila net profit marginya tinggi atau mendekati nilai penjualan yang mereka targetkan. Di samping itu menurut Kasmir (2012) net profit margin adalah ukuran keuntungan dengan membandingkan antara laba setelah bunga dan pajak dan pejualan. Menurut Harahap (2011) menyatakan net profit margin menunjukkan kemampuan perusahaan dalam menghasilkan laba dari tingkat volume usaha tertentu sebagai tingkat efisiensi yang ada di perusahaan. 
Rasio gross profit margin merupakan margin laba kotor. Mengenai gross profit margin Lyn M. Fraser dan Aileen Ormiston di kutip dalam Fahmi (2015) memberikan pendapat yaitu, margin laba kotor adalah margin laba yang memperlihatkan hubungan antara penjualan dan beban pokok penjualan,mengukur kemampuan sebuah perusahaan untuk mengendalikan biaya persediaan atau biaya operasi barang maupun untuk meneruskan kenaikan harga lewat penjualan kepada pelanggan. Lebih jauh Joel G. Siegel dari Fahmi (2015) mengatakan bahwa persentase dari sisa penjualan setelah sebuah perusahaan membayar barangnya juga disebut margin keuntungan kotor. Margin laba kotor ini merupakan suatu indikator penting karena dapat memberikan informasi kepada manajemen maupun investor tentang seberapa untungnya kegiatan bisnis yang dijalankan oleh suatu perusahaan. Semakin tinggi margin laba kotornya maka semakin baik keadaan operasi perusahaannya.

Tabel 1. Pertumbuhan Laba Bersih PT XL Axiata Tbk dan PT Telekomunikasi Indonesia Tbk periode 2017-2019

\begin{tabular}{lll}
\hline Tahun & PT Telekomunikasi Indonesia Tbk & PT XL Axiata Tbk \\
\hline 2017 & Rp 32.701.000.000 & $\operatorname{Rp~375.000.000~}$ \\
2018 & $\operatorname{Rp} 26.979 .000 .000$ & $\operatorname{Rp~} 3.297 .000 .000)$ \\
2019 & $\operatorname{Rp} 27.592 .000 .000$ & $\operatorname{Rp~713.000.000~}$ \\
\hline
\end{tabular}

Sumber : data keuangan dari web perusahaan, diolah 2021

Dari data pada tabel 1, terlihat bahwa pada masing-masing perusahaan mulai dari tahun 2017 sampai dengan tahun 2019 memiliki laba bersih yang berfluktuasi. Ditahun 2017 laba bersih yang diperoleh PT Telekomunikasi Indonesia Tbk adalah sebesar Rp32.701.000.000, pada tahun 2016 kembali mengalami penurunan yaitu dengan perolehan laba bersih sebesar Rp26.979.000.000 dan pada tahun 2019 mengalami peningkatan kembali yaitu sebesar Rp27.592.000.000 disebabkan pendapatan penjualan yang meningkat.

Perolehan laba bersih tahun 2017 PT XL Axiata Tbk adalah sebesar Rp375.000.000,sedangkan pada tahun 2018 mengalami kerugian akibat menurunya laba bersih sebesar $\operatorname{Rp}(3.297 .000 .000)$ dan pada tahun 2019 mengalami peningkatan kembali dengan perolehan laba bersih sebesar Rp713.000.000 karena pendapatan penjualan yang meningkat.

Berdasarkan uraian tersebut maka masalah yang dapat diangkat oleh peneliti adalah apakah terdapat perbedaan net profit margin dan gross profit margin pada perusahaan PT Telekomunikasi Indonesia Tbk dan PT XL Axiata Tbk. Penelitian ini memiliki tujuan untuk mengetahui serta menganalisis perbandingan net profit margin dan gross profit margin pada perusahaan PT Telekomunikasi Indonesia Tbk dan PT XL Axiata Tbk. 


\section{TINJAUAN PUSTAKA}

\section{Laporan Keuangan}

Menurut Kasmir (2016) laporan yang menunjukkan kondisi keuangan pada saat ini atau dalam suatu periode tertentu.Sedangkan menurut Harahap (2011) laporan keuangan adalah laporan keuangan yang menggambarkan kondisi keuangan dan hasil usaha suatu perusahaan pada saat tertentu atau jangka waktu tertentu.Dengan melihat laporan keuangan suatu perusahaan akan tergambar didalamnya aktivitas perusahaan tersebut. Laporan keuangan perusahaan merupakan hasil dari suatu proses akuntansi yang dapat digunakan sebagai alat untuk komunikasi dan juga digunakan sebagai alat pengukur kinerja perusahaan. Menurut Hery (2012) menyatakan bahwa laporan keuangan pada dasarnya hasil dari proses akuntansi yang dapat digunakan sebagai alat ukur mengkomunikasikan data keuangan atau aktivitas perusahaan kepada pihak pihak yang berkepentingan.

\section{Analisis Laporan Keuangan}

Menurut Harmono (2015) analisis laporan keuangan merupakan alat analisis bagi manajemen keuangan perusahaan yang bersifat menyeluruh, dapat digunakan untuk mendeteksi atau mendiagnosis kondisi keuangan pada saat ini atau dalam suatu periode tertentu. Menurut Harahap (2015) menyatakan bahwa analisis laporan keuangan menguraikan pos pos laporan keuangan menjadi unit informasi yang lebih kecil dan melihat hubungannya yang bersifat signifikan yang mempunyai makna antar satu dengan yang lain baik antara data kondisi keuangan maupun non keuangan yang bertujuan untuk mengetahui kondisi keuangan lebih dalam dan sangat penting dalam proses menghasilkan keputusan yang tepat.

\section{Rasio Keuangan}

Rasio keuangan adalah membandingkan angka-angka yang ada dalam laporan keuangan untuk mengetahui posisi keuangan suatu perusahaan serta menilai kinerja manajemen dalam suatu periode tertentu. James C Van Horne dikutip dari Kasmir (2016) Definisi rasio keuangan merupakan indeks yang menghubungkan dua angka akuntansi dan diperoleh dengan membagi satu angka dengan angka lainnya. Rasio keuangan digunakan untuk mengevaluasi kondisi keuangan dan kinerja perusahaan. Menurut Harahap (2013) Rasio keuangan adalah angka yang diperoleh dari hasil perbandingan dari suatu pos laporan keuangan dengan pos lainnya yang mempunyai hubungan yang relevan dan signifikan. Kemudian angka yang diperbandingkan dapat berupa angka-angka dalam satu periode maupun beberapa periode. Rasio keuangan sangat penting dalam melakukan analisis terhadap kondisi keuangan perusahan. Pengukuran rasio keuangan yang di gunakan dalam penelitian ini adalah sebagai berikut: 


\section{Net Profit Margin}

Menurut Fahmi (2015) rasio ini di sebut juga dengan rasio pendapatan terhadap penjualan. Pebrianti dan Kurniawan (2017) berpendapat net profit margin adalah rasio yang mengukur laba bersih setelah pajak terhadap penjualan. Menurut Murhadi (2013) net profit margin adalah mencerminkan kemampuan perusahaan dalam menghasilkan laba neto dari setiap penjualannya.semakin tinggi net profit margin maka menunjukkan semakin baik. Menurut (Kasmir, 2016) net profit margin dikatakan baik adalah di atas $20 \%$.

Rumus net profit margin $=\frac{\text { laba setelah bunga dan pajak }}{\text { penjualan }} \times 100 \%$

\section{Gross Profit Margin}

Menurut (Martono.agus harjito, 2014) gross profit margin adalah perbandingan penjualan bersih dikurangi harga pokok penjualan dengan penjualan bersih atau rasio antara laba kotor dengan penjualan bersih. Menurut Munawir (2010) gross profit margin adalah rasio atau perimbangan antara gross profit laba (laba kotor) yang diperoleh perusahaan dengan tingkat penjualan yang dicapai pada periode yang sama. Menurut Murhadi (2013) gross profit margin adalah menggambarkan presentasi laba kotor yang dihasilkan oleh setiap pendapatan perusahaan, semakin tinggi gross profit margin maka akan menunjukkan semakin baik. Menurut Hery (2018) standar gross profit margin industri adalah $30 \%$

Rumus gross profit margin $=\frac{\text { laba sebelum bunga dan pajak }}{\text { penjualan }} \times 100 \%$

Menurut Hery (2012) menyatakan bahwa analisis rasio keuangan merupakan analisis yang paling sering dilakukan untuk menilai kondisi keuangan dan kinerja perusahaan dibandingkan dengan alat analisis keuangan lainnya. Menurut Munawir (2010) berdasarkan tekniknya, analisis keuangan dapat dibedakan menjadi 9 yaitu: analisis perbandingan laporan keuangan, analisis tren, analisis persentase per komponen (common size), analisis sumber dan penggunaan modal kerja, analisis sumber dan penggunakan kas, analisis rasio keuangan, analisis perubahan laba kotor, analisis titik impas. Untuk membantu analisis data penelitian maka dapat dikembangkan dengan kerangka pemikiran pada gambar 1 berikut ini. 


\section{Gambar 1. Kerangka Pemikiran}

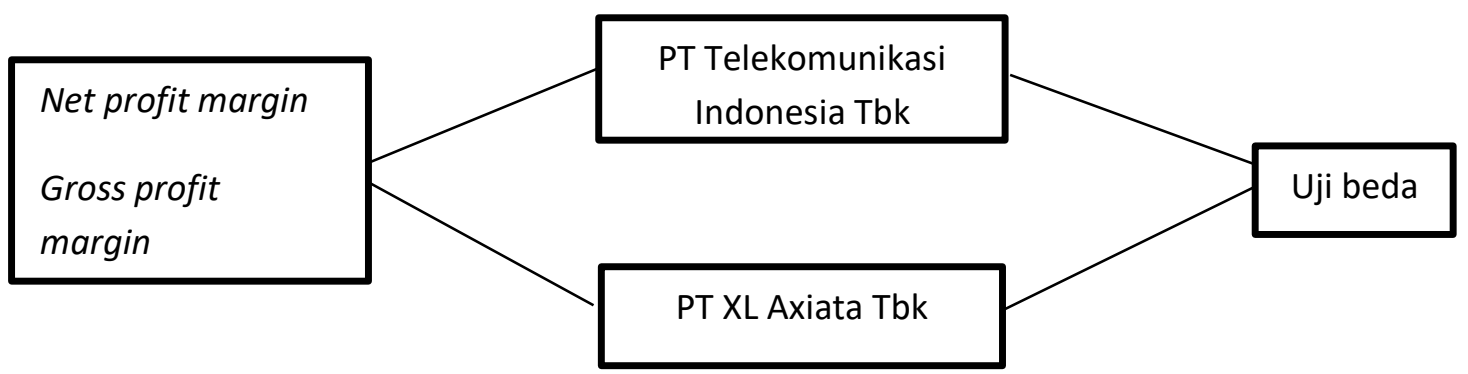

Dalam penelitian Lahallo (2019) mengatakan bahwa nilai rata-rata NPM antara PT XL Axiata dan PT Indosat tidak berbeda secara statistik, sedangkan nilai rata-rata NPM pada PT Telekomunikasi Indonesia dan PT XL Axiata berbeda. Nugrahanti dan Fuadati (2019) berkesimpulan bahwa berdasarkan perhitungan net profit margin dengan menggunakan uji beda serta menggunakan spps 23 menunjukkan bahwa probabilitas signifikansi yaitu $0,388>0,05$ sehingga disimpulkan bahwa tidak terdapat perbedaan yang signifikan antara PT Telekomunikasi Indonesia Tbk dan PT XL Axiata Tbk.

Asyikin dan Tanu (2011) dalam penelitiannya menyimpulkan bahwa NPM dan GPM pada perusahaan farmasi milik pemerintah dan perusahaan farmasi milik swasta memiliki perbedaan yang nyata melalui uji independent sample t test. Dari penelitian terdahulu di atas maka peneliti merumuskan hipotesis sebagai berikut

Menurut (Sugiyono, 2014) hipotesis komparatif merupakan jawaban sementara terhadap rumusan masalah komparatif. Pada rumusan ini variabelnya sama tetapi populasi atau sampelnya yang berbeda, atas keadaan itu terjadi pada waktu yang berbeda. Maka perumusan hipotesisnya adalah sebagai berikut:

$\mathrm{H} 0: \mu 1=\mu 2$ Tidak ada perbedaan net profit margin (npm) pada PT Telekomunikasi Indonesia Tbk dan PT XL Axiata Tbk

Ha : $\mu 1 \neq \mu 2$ Ada perbedaan net profit margin (npm) pada PT Telekomunikasi IndonesiaT bk dan PT XL Axiata Tbk

$\mathrm{H} 0: \mu 1=\mu 2$ Tidak ada perbedaan gross profit margin (gpm) pada PT telekomunikasi Indonesia Tbk dan PT XL Axiata tbk

Ha : $\mu 1 \neq \mu 2$ Ada perbedaan gross profit margin (gpm) pada PT Telekomunikasi Indonesia Tbk dan PT XL Axiata Tbk

\section{METODE PENELITIAN}

\section{Jenis Penelitian}

Penelitian ini merupakan penelitian kuantitatif dengan menggunakan studi komparatif. Penelitian komparatif adalah jenis penelitian yang digunakan untuk 
membandingkan antara dua kelompok atau lebih dari satu variabel tertentu. Kindangen (2016) menyatakan bahwa komparatif adalah penelitian yang bersifat membandingkan.

\section{Instrumen Penelitian}

Instrumen penelitian yang digunakan dalam penelitian ini adalah dokumentasi data laporan keuangan berupa laporan laba rugi yang di akses melalui web kedua perusahaan, dan studi pustaka berupa penelitian-penelitian terdahulu

\section{Populasi dan Sampel Penelitian}

Menurut Sugiyono (2011) populasi adalah wilayah generasi yang terdiri atas obyek atau subyek yang mempunyai kualitas dan karakteristik tertentu yang ditetapkan oleh peneliti untuk dipelajari dan kemudian ditarik kesimpulannya. Populasi yang dipakai adalah seluruh data laporan keuangan laba rugi berupa penjualan atau pendapatan,laba setelah pajak dan laba sebelum pajak dari perusahaan PT Telekomunikasi Indonesia tbk selama 24 tahun mulai dari tahun (1995-2019) dan PT XL Axiata tbk selama 14 tahun yang dimulai dari tahun (2005-2019)

Teknik Pengambilan sampel yang digunakan dalam penelitian ini adalah purposive sampling. Menurut Sugiyono (2014) purposive sampling merupakan teknik penentuan sampel dengan pertimbangan tertentu yang di gunakan sehingga sampel penelitian ini menjadi 10 tahun dan merupakan data terbaru.

\section{Teknik Pengumpulan Data}

Teknik pengumpulan data yang digunakan dalam penelitian ini adalah dokumentasi, berupa data sekunder laporan keuangan (laba rugi) PT Telekomunikasi Indonesia Tbk dan PT XL Axiata Tbk yang terdaftar di Bursa Efek Indonesia dan web resmi kedua perusahaan serta studi pustaka yang berupa referensi-referensi terdahulu.

\section{Teknik Analisis Data}

Teknik analisis data yang digunakan dalam penelitian ini adalah : Menghitung rasio-rasio keuangan PT Telekomunikasi Indonesia Tbk dan PT XL Axiata Tbk yang terdiri dari rasio net profit margin dan gross profit margin, melakukan uji normalitas, serta menganalisis dan membandingkan net profit margin dan gross profit margin PT Telekomunikasi Indonesia Tbk dan PT XL Axiata Tbk dengan Uji Beda (Independent sampel test) menggunakan IBM SPSS 16

Uji normalitas pada penelitian ini menggunkan uji normalitas dengan metode kolmogorov smirnov. Menurut Ghozali (2016) uji statistik lain yang dapat di gunakan untuk menguji normalitas residual adalah uji statistik non-parametrik kolmogorov smirnov. Pengambilan keputusan :

Jika nilai signifikansi $>0,05$ maka data tersebut berdistribusi normal Jika nilai signifikansi $<0,05$ maka data tersebut tidak berdistribusi normal. 
Uji beda (Independent sample test), menurut Ghozali (2016) uji beda t-test digunakan untuk menentukan apakah dua sampel yang tidak berhubungan memiliki nilai rata-rata yang berbeda. Jadi tujuan uji beda test adalah membandingkan rata-rata dua grup yang tidak berhubungan satu dengan yang lain. Apakah kedua grub tersebut mempunyai nilai rata-rata yang sama ataukah tidak sama secara signifikan. Selanjutnya dengan menggunakan tingkat signifikansi untuk mengetahui perbedaan rasio keuangan kedua perusahaan tersebut apakah ada perbedaan atau tidak ada perbedaan. Pengolahan data dalam uji hipotesis ini menggunakan program IBM SPSS 16

\section{HASIL DAN DISKUSI}

\section{A. Pembahasan Hasil Analisis Data}

Tabel 2. Analisis Rasio Keuangan Net Profit Margin (NPM) dan Gross Profit Margin (GPM) PT Telekomunikasi Indonesia Tbk (TLKM) dan PT XL Axiata Tbk (EXCL) Periode 2010-2019

\begin{tabular}{llllllllllll}
\hline & $\mathbf{2 0 1 0}$ & $\mathbf{2 0 1 1}$ & $\mathbf{2 0 1 2}$ & $\mathbf{2 0 1 3}$ & $\mathbf{2 0 1 4}$ & $\mathbf{2 0 1 5}$ & $\mathbf{2 0 1 6}$ & $\mathbf{2 0 1 7}$ & $\mathbf{2 0 1 8}$ & $\mathbf{2 0 1 9}$ & RATA-RATA \\
\hline NPM TLKM & $23,12 \%$ & $21,71 \%$ & $23,80 \%$ & $24,46 \%$ & $23,72 \%$ & $22,75 \%$ & $25,08 \%$ & $25,50 \%$ & $20,63 \%$ & $20,35 \%$ & $23,11 \%$ \\
GPM TLKM & $31,21 \%$ & $29,27 \%$ & $31,41 \%$ & $32,72 \%$ & $31,90 \%$ & $30,59 \%$ & $32,83 \%$ & $33,26 \%$ & $27,84 \%$ & $27,96 \%$ & $30,89 \%$ \\
NPM EXCL & $16,39 \%$ & $15,32 \%$ & $12,99 \%$ & $4,84 \%$ & $(3,78 \%)$ & $(0,11 \%)$ & $1,76 \%$ & $1,64 \%$ & $(14,33 \%)$ & $2,83 \%$ & $3,75 \%$ \\
GPM EXCL & $21,93 \%$ & $20,93 \%$ & $17,63 \%$ & $6,51 \%$ & $(4,54 \%)$ & $(2,74 \%)$ & $0,87 \%$ & $0,97 \%$ & $(19,11 \%)$ & $4,55 \%$ & $4,69 \%$ \\
\hline
\end{tabular}

Sumber: data sekunder, diolah 2021

Berdasarkan tabel 2, rata-rata NPM pada PT Telekomunikasi Indonesia Tbk dikategorikan baik karena berada di atas standar rasio yaitu $>20 \%$. Hal ini dapat diartikan bahwa perusahaan di anggap mampu dalam menghasilkan laba bersih atas penjualan. Sedangkan hasil perhitungan NPM pada PT XL Axiata Tbk dikategorikan kurang baik karena berada di bawah standar rasio yaitu di bawah 20\%, dapat diartikan bahwa perusahaan kurang mampu dalam menghasilkan laba bersih atas penjualan. Hasil perhitungan GPM pada PT Telekomunikasi Indonesia Tbk dikategorikan baik karena berada di atas standar rasio yaitu di atas 30\%, hal ini diartikan bahwa perusahaan di anggap mampu menghasilkan laba kotor atas penjualan, sedangkan GPM pada PT XL Axiata Tbk dikategorikan kurang baik karena berada di bawah standar rasio yaitu di bawah 30\%, dalam hal ini diartikan bahwa perusahaan kurang mampu menghasilkan laba kotor atas penjualan.

\section{B. Uji normalitas}

Tabel 3. Uji normalitas data

\begin{tabular}{lcc}
\hline & \multicolumn{2}{c}{ Kolmogorov smirnov } \\
\hline & statistic & sig. \\
Net profit margin TLKM & .186 & .200 \\
Gross profit margin TLKM & .233 & .132 \\
Net profit margin EXCL & .174 & .200 \\
Gross profit margin EXCL & .151 & .200 \\
\hline sumber: data sekunder, diolah 2021 & &
\end{tabular}


Berdasarkan output SPSS bahwa nilai sig. > 0,05 yang berkesimpulan bahwa data yang diuji berdistribusi normal.

\section{Perbandingan Dengan Uji Beda (Independent Samples t-Test)}

Untuk mengetahui apakah ada perbedaan atau tidak terdapat perbedaan pada NPM dan GPM pada perusahaan PT Telekomunikasi Indonesia Tbk dan PT XL Axiata Tbk maka dilakukan perbandingan dengan melakukan uji beda (independent sample test). Uji beda ini dilakukan dengan bantuan SPSS. Pada penelitian ini tingkat signifikan yang ditetapkan untuk seluruh pengujian adalah $\alpha$ sebesar 0,05 . Jika probabilitas > 0,05 maka $\mathrm{H} 0$ diterima dan Ha ditolak Jika probabilitas < 0,05 maka $\mathrm{H} 0$ ditolak dan Ha diterima

a. Apabila H0 diterima dan Ha ditolak, artinya tidak terdapat perbedaan antara NPM dan GPM antara PT Telekomunikasi Indonesia Tbk dan PT XL Axiata Tbk

b. Apabila H0 ditolak dan Ha diterima, artinya terdapat perbedaan NPM dan GPM antara PT Telekomunikasi Tbk dan PT XL Axiata Tbk

Berdasarkan perhitungan dengan menggunakan uji beda independent samples test dan menggunakan SPSS versi 16, maka dapat diketahui hasil dari penelitian ini apakah ada perbedaan yang signifikan antara NPM dan GPM PT Telekomunikasi Indonesia Tbk dan PT XL Axiata Tbk, atau tidak ada perbedaan antara NPM dan GPM PT Telekomunikasi Indonesia dan PT XL Axiata Tbk.

\section{a. Rasio Net Profit Margin ( NPM )}

Tabel 4. Hasil Uji Beda Independent Samples Test Menggunakan Spss 16

\begin{tabular}{|c|c|c|}
\hline & $\begin{array}{c}\text { Levene's Test for Equality } \\
\text { of Variance }\end{array}$ & t-Test For Equality of Means \\
\hline & $\mathrm{F} \quad$ sig & sig. (2-tailed) \\
\hline $\begin{array}{l}\text { NPM Equal variances } \\
\text { assumed }\end{array}$ & 8.148 & 6.578 \\
\hline $\begin{array}{l}\text { Equal variances not } \\
\text { Assumed }\end{array}$ & & 6.578 \\
\hline
\end{tabular}

Gambar 2. Kurva Hipotesis

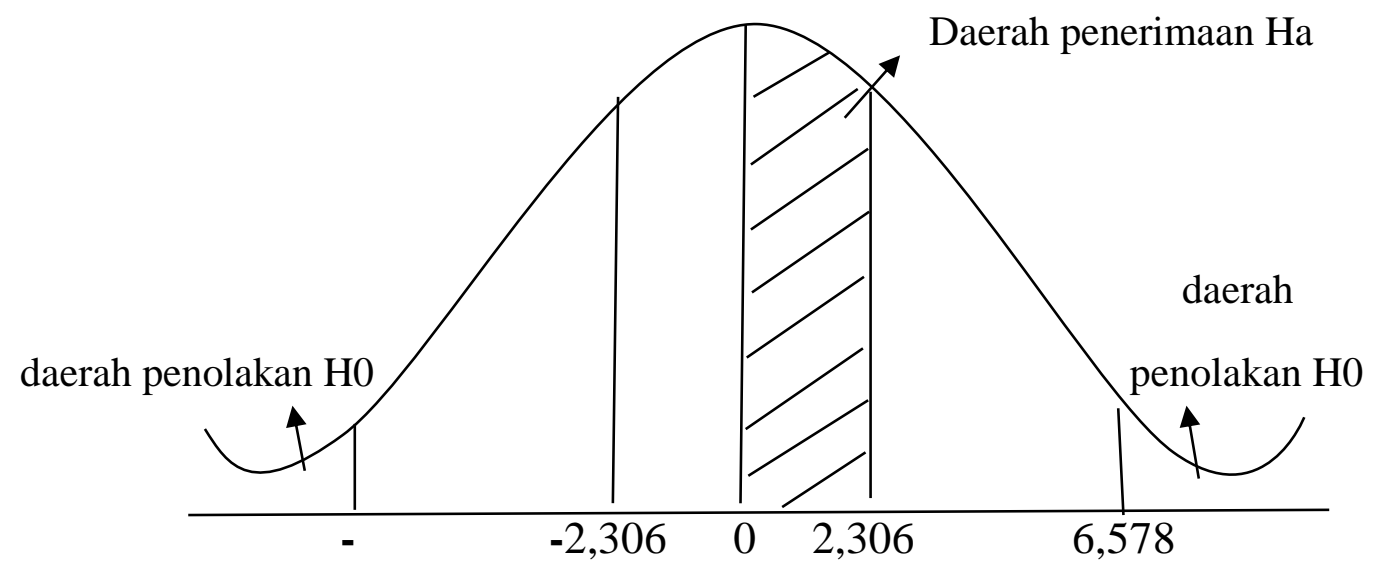


Berdasarkan output SPSS terlihat bahwa nilai probabilitas signifikansi (two tailed) sebesar 0,000 < 0,05, Sebagaimana dasar pengambilan keputusan maka H0 ditolak dan Ha diterima dengan kesimpulan terdapat perbedaan antara net profit margin PT Telekomunikasi Indonesia Tbk dan PT XL Axiata Tbk.

Jika dilihat dari nilai $t$ hitung dan $t$ tabel, nilai $t$ hitung adalah sebesar 6,578. Untuk melihat $\mathrm{t}$ tabel dengan menggunakan rumus $(\alpha / 2):(\mathrm{df})=(0,05 / 2):(8)=0,025: 8$. maka dapat ditemukan nilai t tabel dari tabel distribusi adalah sebesar 2,306. Dengan demikian nilai t hitung sebesar 6,578 > t tabel 2,306 , maka berdasarkan dasar pengambilan keputusan dengan melihat perbandingan $\mathrm{t}$ hitung dan $\mathrm{t}$ tabel dapat disimpulkan bahwa terdapat perbedaan antara net profit margin PT Telekomunikasi Indonesia Tbk dan PT XL Axiata Tbk

\section{b. Rasio Gross Profit Margin (Gpm)}

Tabel 5. Hasil Uji Beda Independent Samples Test Menggunakan Spss 16

\begin{tabular}{|c|c|c|c|}
\hline & $\begin{array}{c}\text { Levene's Test for Equality } \\
\text { of Variances }\end{array}$ & \multicolumn{2}{|c|}{ t-Test For Equality of Means } \\
\hline & $\mathrm{F} \quad$ sig & $\mathrm{t}$ & sig. (2-tailed) \\
\hline $\begin{array}{l}\text { GPM Equal variances } \\
\text { Assumed }\end{array}$ & $10.452 \quad .005$ & 6.554 & .000 \\
\hline $\begin{array}{l}\text { Equal variances not } \\
\text { Assumed }\end{array}$ & & 6.554 & .000 \\
\hline
\end{tabular}

Gambar 3. Kurva Hipotesis

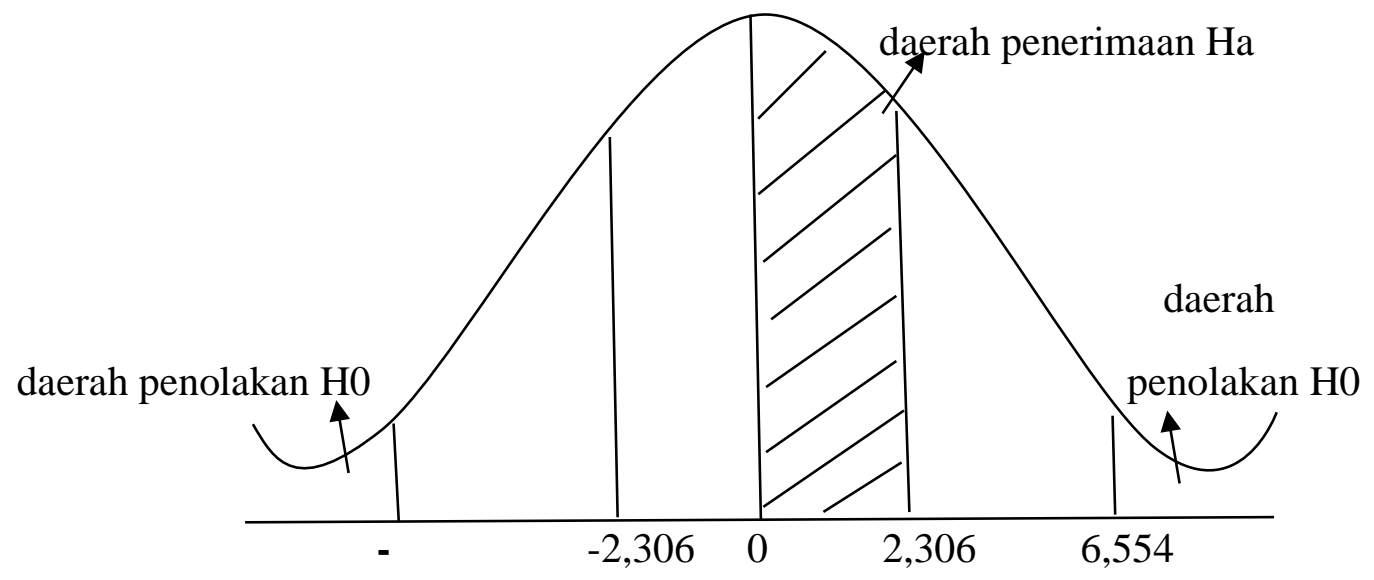

Berdasarkan output SPPS dapat dilihat bahwa probabilitas signifikansi (two tail) sebesar $0,000<0,05$, sebagaimana dasar pengambilan keputusan maka H0 ditolak dan Ha diterima dengan kesimpulan terdapat perbedaan antara gross profit margin PT Telekomunikasi Indonesia Tbk dan PT XL Axiata Tbk.

Jika di lihat dari nilai t hitung dan $t$ tabel, nilai t hitung adalah sebesar 6,554. Untuk melihat $\mathrm{t}$ tabel dengan menggunakan rumus $(\alpha / 2):(\mathrm{df})=(0,05 / 2):(8)=0,025$ : 8. Maka dapat ditemukan nilai t tabel dari tabel distribusi adalah sebesar 2,306. Dengan demikian nilai t hitung sebesar 6,554 > t tabel 2,306, maka berdasarkan dasar pengambilan keputusan dengan melihat perbandingan $t$ hitung dan $t$ tabel dapat 
disimpulkan bahwa terdapat perbedaan antara gross profit margin PT Telekomunikasi Indonesia Tbk dan PT XL Axiata Tbk

\section{KESIMPULAN DAN SARAN}

\section{Kesimpulan}

Berdasarkan output SPSS terlihat bahwa nilai probabilitas signifikansi (two tailed) sebesar 0,000 $<0,05$, Sebagaimana dasar pengambilan keputusan maka $\mathrm{H} 0$ ditolak dan Ha diterima dengan kesimpulan terdapat perbedaan antara net profit margin PT Telekomunikasi Indonesia Tbk dan PT XL Axiata Tbk.

Jika dilihat dari nilai t hitung dan t tabel, nilai t hitung adalah sebesar 6,578. Untuk melihat $\mathrm{t}$ tabel dengan menggunakan rumus $(\alpha / 2):(\mathrm{df})=(0,05 / 2):(8)=0,025: 8$. maka dapat ditemukan nilai t tabel dari tabel distribusi adalah sebesar 2,306. Dengan demikian nilai $\mathrm{t}$ hitung sebesar 6,578 > t tabel 2,306, maka berdasarkan dasar pengambilan keputusan dengan melihat perbandingan $t$ hitung dan $t$ tabel dapat disimpulkan bahwa terdapat perbedaan antara net profit margin PT Telekomunikasi Indonesia Tbk dan PT XL Axiata Tbk

Berdasarkan output SPPS dapat dilihat bahwa probabilitas signifikansi (two tail) sebesar $0,000<0,05$, sebagaimana dasar pengambilan keputusan maka $\mathrm{H} 0$ ditolak dan Ha diterima dengan kesimpulan terdapat perbedaan antara gross profit margin PT Telekomunikasi Indonesia Tbk dan PT XL Axiata Tbk. Jika di lihat dari nilai t hitung dan $\mathrm{t}$ tabel, nilai $\mathrm{t}$ hitung adalah sebesar 6,554. Untuk melihat $\mathrm{t}$ tabel dengan menggunakan rumus $(\alpha / 2):(\mathrm{df})=(0,05 / 2):(8)=0,025: 8$. Maka dapat ditemukan nilai t tabel dari tabel distribusi adalah sebesar 2,306. Dengan demikian nilai t hitung sebesar 6,554 > t tabel 2,306, maka berdasarkan dasar pengambilan keputusan dengan melihat perbandingan $t$ hitung dan $\mathrm{t}$ tabel dapat disimpulkan bahwa terdapat perbedaan antara gross profit margin PT Telekomunikasi Indonesia Tbk dan PT XL Axiata Tbk

\section{Saran}

Berdasarkan hasil penelitian bahwa dari tingkat laba bersih (NPM) dan laba kotor (GPM) perusahaan PT Telekomunikasi Indonesia Tbk lebih unggul di bandingkan PT XL Axiata Tbk, dan perbandingan NPM dan GPM kedua perusahaan tersebut memiliki perbedaan yang signifikan. Untuk peneliti selanjutnya agar menambahkan variabel lain di luar variabel yang di teliti. Bagi kedua perusahaan yang di teliti, sekiranya penjualan lebih di tingkatkan lagi agar pendapatan juga ikut membaik

\section{DAFTAR PUSTAKA}

Asyikin, J., \& Tanu, V. S. (2011). Analisis Perbandingan Kinerja Keuangan Antara Perusahaan Farmasi Milik Pemerintah (Bumn) Dengan Perusahaan Farmasi Swasta Yang Terdaftar Di Bursa Efek Indonesia. Jurnal Spread, 1(1), 36-48. 
http://journal.stiei-kayutangi-bjm.ac.id/index.php/jibk/article/view/70/68

Fahmi, I. (2015). Pengantar Manajemen Keuangan Teori dan Soal Jawab. Alfabeta.

Ghozali, I. (2016). Aplikasi Analisis Multivariate dengan Program IBM SPSS 23. Badan Penerbit Universitas Diponegoro.

Harahap. (2011). Analisis Ktitis Atas Laporan Keuangan (Cetakan Ke). PT Grafindo Persada.

_. (2013). Analisis Kristis Atas Laporan Keuangan. PT Raja Grafindo Persada.

_ (2015). Analisis Ktitis Atas Laporan Keuangan. Rajawali Pers.

Harmono. (2015). Manajemen Keuangan Berbasis Balanced Scorecard Pendekatan

Teori,Kasur,dan Riset Bisnis (Cetakan Pe). Bumi Aksara.

Hery. (2012). Analisis Laporan Keuangan. Bumi Aksara.

— . (2018). Analisis Laporan Keuangan (cetakan Ke). PT Grasindo.

Irham Fahmi. (2014). Pengantar Manajemen Keuangan. CV Alfabeta.

Jumingan. (2008). Analisis Laporan Keuangan. Bumi Aksara.

Kasmir. (2009). Analisis Laporan Keuangan. PT Raja Grafindo Persada.

—. (2016). Analisis Laporan Keuangan. PT Grafindo Persada.

Kindangen. (2016). Analisis Perbandingan Kinerja Keuangan Pada Perusahaan

Telekomunikasi yang Terdaftar di BEI Periode 2011-2014 (Studi Kasus pada PT

Telekomunikasi Indonesia Tbk dan PT XL Axiata Tbk). Jurnal Berkala Ilmiah

Efisiensi, 16(3), 102-110.

Lahallo, F. F. (2019). Perbandingan Kinerja Keuangan Perusahaan Telekomunikasi

Yang Terdaftar Di Bursa Efek Indonesia Periode 2008 - 2017 (Studi Kasus Pada

Pt. Telekomunikasi Indonesia Tbk, Pt. Indosat Tbk, Dan Pt. Xl Axiata Tbk).

Buletin Studi Ekonomi, 23(2), 269. https://doi.org/10.24843/bse.2018.v23.i02.p09

Martono.agus harjito. (2014). Analsisi Laporan Keuangan. Ekonesia.

Munawir, S. (2010). Analisis Laporan Keuangan. Liberty.

Murhadi, W. . (2013). Analisis Laporan Keuangan,Proyeksi dan Valuas saham. 
Salemba empat.

Ni Wayan Sri Pebriyanti, Putu Sukma Kurniawan, E. S. (2017). ANALISIS PERBANDINGAN RASIO-RASIO KEUANGAN DAN DAMPAKNYA TERHADAP KELANGSUNGAN BISNIS BADAN USAHA MILIK DESA

(Studi Kasus Pada BUMDes di Kabupaten Klungkung). E-Jurnal S1 Ak Universitas Pendidikan Ganesha, 1(1), 1-12.

Nugrahanti, C. A., \& Fuadati, S. R. (2019). Analisis Perbandingan Kinerja Keuangan Pada PT. Telekomunikasi Indonesia Tbk dan PT. XL Axiata Tbk. Jurnal Ilmu Dan Riset Manajemen, 8, 1-18.

Pratowo, dwi. (2011). Analisis Laporan Keuangan Konsep Dan Aplikasi (Edisi Revi). UUP AMK YKPN.

Sugiyono. (2011). Metode Penelitian Kuantitatif Kualitatif dan R\&B. Alfabeta. (2014). Metode Penelitian Bisnis. CV Alfabeta. 